\title{
Energy and nitrogen balances in very low birthweight infants
}

\author{
M DE CURTIS AND O G BROOKE \\ Department of Child Health, St George's Hospital, London and Neonatal Unit, Second School of Medicine, \\ Naples, Italy
}

SUMMARY Energy and nitrogen balances were performed in 12 very low birthweight infants fed on either human milk or on a preterm formula. Energy and nitrogen retention were significantly higher in those given the formula feed $(p<0.05)$. Highly significant correlations were found between nitrogen intake and nitrogen retention and between energy retention and nitrogen retention $(\mathrm{p}<0 \cdot 001)$. Multiple regression analysis failed to show any effect of energy retention on the correlation between nitrogen intake and nitrogen retention in babies fed on human milk. Protein deficiency seems to be the most likely explanation of poor growth in infants fed on human milk.

During the past few years many studies of metabolic balance in preterm infants fed on expressed human milk or preterm formulas have been reported, but few have concerned very low birthweight infants $(<1500 \mathrm{~g}) .{ }^{12}$ These infants are the most vulnerable to nutritional deficiencies, the most immature in metabolic development, and the most likely to suffer impaired growth and the other sequelae of poor nutrition.

This study aimed to compare the results of metabolic balance studies and to examine the association between energy balance and nitrogen balance in two groups of such infants, fed either human milk or a preterm formula.

\section{Patients and methods}

The 12 babies studied were all premature infants admitted to the neonatal unit at St George's Hospital. They all weighed less than $1500 \mathrm{~g}$, both at birth and on entry to the study, were well, and gaining weight. Some of them had already had metabolic balance studies. ${ }^{3}$

Table 1 gives details of their birth weight and gestational age: none had any congenital abnormality. They were in air mode controlled (not servo controlled) incubators during the study. Informed consent was obtained from the parents, and the studies were approved by the hospital ethical committee.

Three day balances were performed on 23 occasions in 12 very low birthweight infants. Eight infants were fed on human milk (six from their own mothers, unheated, and two from the milk bank, pasteurised), and four were fed on a preterm formula (Pre-Aptamil, Milupa Ltd), the composition of which is given in Table 2. A sample of human milk used for each balance was taken for analysis. Pre-Aptamil of the same lot (No 222104) was also analysed, but as the composition of milk is constant we did not analyse it more than once. The volume taken at each feed was measured using a $20 \mathrm{ml}$ syringe.

Balances were measured over three days, a carmine marker being given at the beginning and

Table 1 Details of infants studied

\begin{tabular}{lll}
\hline & $\begin{array}{l}\text { Human milk } \\
15 \text { balances } \\
\text { mean }(S D)\end{array}$ & $\begin{array}{l}\text { Pre-Aptamil } \\
8 \text { balances } \\
\text { mean (SD) }\end{array}$ \\
\hline Birth weight (g) & $1016(235)$ & $1133(164)$ \\
Gestational age (weeks) & $28 \cdot 4(2 \cdot 8)$ & $28 \cdot 5(1 \cdot 7)$ \\
Age at the beginning of balance (days) & $31(29)$ & $17(10)$ \\
Weight at the beginning of balance (g) & $1243(218)$ & $1258(108)$ \\
\hline
\end{tabular}

Table 2 Composition of $100 \mathrm{ml}$ Pre-Aptamil

\begin{tabular}{ll}
\hline Energy & $309 \mathrm{~kJ}$ \\
Protein & $2 \cdot 1 \mathrm{~g}$ \\
Lactalbumin:casein & $48: 52$ \\
Fat & $3 \cdot 6 \mathrm{~g}$ \\
Fat blend & Vegetable oils + butter fat \\
Carbohydrate (lactose) & $8 \cdot 7 \mathrm{~g}$ \\
Osmolality & $350 \mathrm{mOsm} / \mathrm{kg}$ \\
\hline
\end{tabular}

$(1 \mathrm{kcal}=4 \cdot 184 \mathrm{~kJ})$. 
end of each study period. All stools passed during the period were collected in nappy liners and immediately frozen at $-20^{\circ} \mathrm{C}$. They were later weighed, freeze dried, weighed again, homogenised, and analysed for energy and for nitrogen balances using the bomb calorimeter, ${ }^{4}$ and the Kjeldahl technique with the Kjeltec apparatus, ${ }^{5}$ respectively.

Urine was collected in nitrogen free disposable nappies which had been weighed; they were sealed in plastic containers after each change, and immediately frozen at $-20^{\circ} \mathrm{C}$. The nappies were subsequently weighed again to measure the volume of urine, and then washed in a known volume of water. After filtering aliquots were freeze dried and analysed for energy and nitrogen balances. ${ }^{6}$ As stools contain some water that will contaminate the nappy, this method does not separate urine and stools completely.

All infants were weighed daily on a calibrated Marsden spring balance (Marsden Weighing Machines, London), accurate to within $5 \mathrm{~g}$. Weight gain, expressed as $\mathrm{g} / \mathrm{kg} /$ day, was estimated over 10 days which included the three days of the study.

Retention of energy or nitrogen was defined as energy or nitrogen intake $(\mathrm{kcal} / \mathrm{kg}$ or $\mathrm{mg} / \mathrm{kg}$ ) minus (faecal plus urinary energy or nitrogen $(\mathrm{kcal} / \mathrm{kg}$ or $\mathrm{mg} / \mathrm{kg}$ )), expressed as a retention rate in kcal or $\mathrm{mg} / \mathrm{kg}$. The correlations between nitrogen intake and nitrogen retention, and between energy retention and nitrogen retention, were calculated using the methods of least squares and linear regression analysis. The significance of the difference between the arithmetic means was calculated using Student's $t$ test.

\section{Results}

Table 3 shows the intake, output, and balance and growth measurements made during the study in the two groups of infants. There were no significant differences between the volumes of feed/ $\mathrm{kg}$ given daily, hence energy intake was higher in the group fed on Pre-Aptamil than in the group fed on human milk, because the formula has a higher energy density; the energy content of Pre-Aptamil was $81 \mathrm{kcal} / \mathrm{dl}$ and the mean (SD) energy content of human milk $64(9) \mathrm{kcal} / \mathrm{dl}$. The energy retention was significantly higher in the infants fed Pre-Aptamil $(\mathrm{p}<0.05$, Student's $t$ test).

The mean (SD) nitrogen content of human milk was $242(46) \mathrm{mg} / \mathrm{dl}$, and that of Pre-Aptamil 329 (8) $\mathrm{mg} / \mathrm{dl}$. The infants fed human milk received an average of $452 \mathrm{mg}$ of nitrogen/ $\mathrm{kg} /$ day, corresponding to a net protein intake of $2.8 \mathrm{~g} / \mathrm{kg} / \mathrm{day}$. Those fed Pre-Aptamil received an average of $6.6 \mathrm{mg}$ nitrogen/
Table 3 Balance data

\begin{tabular}{|c|c|c|}
\hline & $\begin{array}{l}\text { Human milk } \\
(\text { Mean SD) } \\
(8 \text { infants, } \\
15 \text { balances })\end{array}$ & $\begin{array}{l}\text { Pre-Aptamil } \\
\text { (Mean SD) } \\
\text { (4 infants, } \\
8 \text { balances })\end{array}$ \\
\hline $\begin{array}{l}\text { Milk intake } \\
(\mathrm{ml} / \mathrm{kg} / \text { day })\end{array}$ & $184(15)$ & 187 (17) NS \\
\hline $\begin{array}{l}\text { Energy intake } \\
(\mathrm{kcal} / \mathrm{kg} / \text { day })\end{array}$ & $120(21)$ & 149 (12) $p=0.0018$ \\
\hline $\begin{array}{l}\text { Faecal + urinary } \\
\text { energy (kcal/kg/day) }\end{array}$ & $23(12)$ & 32 (16) NS \\
\hline $\begin{array}{l}\text { Energy retention } \\
(\mathrm{kcal} / \mathrm{kg} / \mathrm{day})\end{array}$ & $97(21)$ & 117 (17) $\mathrm{p}=0.03$ \\
\hline $\begin{array}{l}\text { Energy retention } \\
(\% \text { intake })\end{array}$ & $81(10)$ & 79 (10) NS \\
\hline $\begin{array}{l}\text { Nitrogen intake } \\
(\mathrm{mg} / \mathrm{kg} / \text { day })\end{array}$ & $452(92)$ & $606(41) p=0 \cdot 0002$ \\
\hline $\begin{array}{l}\text { Faecal }+ \text { urinary } \\
\text { nitrogen }(\mathrm{mg} / \mathrm{kg} / \text { day })\end{array}$ & $161(62)$ & $229(55) \mathrm{p}=0.017$ \\
\hline $\begin{array}{l}\text { Nitrogen retention } \\
(\mathrm{mg} / \mathrm{Kg} / \text { day })\end{array}$ & $297(64)$ & $377(62) p=0.009$ \\
\hline $\begin{array}{l}\text { Nitrogen retention } \\
(\% \text { intake })\end{array}$ & $66(10)$ & 62 (9) NS \\
\hline $\begin{array}{l}\text { Weight gain } \\
(\mathrm{g} / \mathrm{Kg} / \text { day })\end{array}$ & $14(6)$ & $17(6) p=0.03$ \\
\hline
\end{tabular}

$\mathrm{kg} / \mathrm{day}$, corresponding to a net protein intake of $3.8 \mathrm{~g} / \mathrm{kg} / \mathrm{day}$. Mean nitrogen retention was significantly higher in infants fed Pre-Aptamil.

The net nitrogen use (nitrogen retention/nitrogen intake) was $66(10)$ in infants fed on human milk, and 62 (9) in those fed Pre-Aptamil. There were no significant differences between the groups. Positive correlations, which were both highly significant, were found between nitrogen retention and nitrogen intake $(r=0.76, p<0.001)$, and between nitrogen retention and energy retention $(r=0.68, p<0.001)$ (Figure).

Using multiple regression analysis, we found that energy retention did not affect the correlation between nitrogen intake and nitrogen retention, either with human milk or with the formula, or when using the combined data.

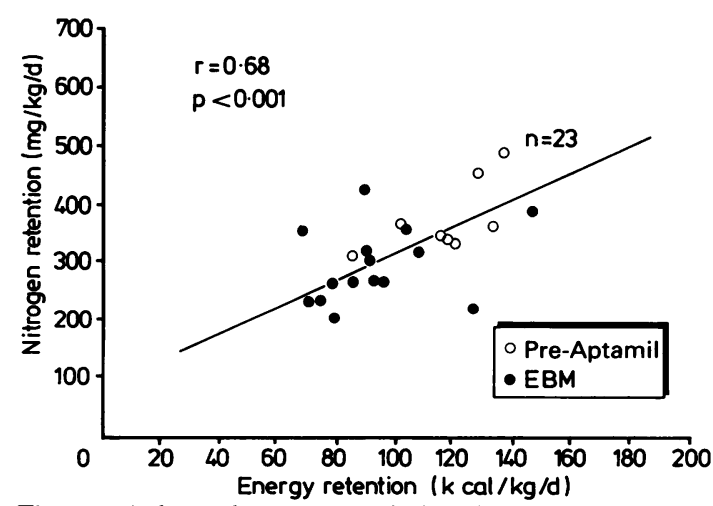

Figure Relation between metabolisable energy and nitrogen retention in very low birthweight infants fed on Pre-Aptamil and expressed breast milk (EBM). 
Mean (SD) weight gain was significantly lower in those infants fed human milk than in those fed PreAptamil, being 14 (6) and 17 (6) $\mathrm{g} / \mathrm{kg} / \mathrm{day}$, respectively $(p=0.03)$.

\section{Discussion}

The aim of this study was to quantify energy and nitrogen retention and the effect of energy retention on nitrogen balance in very low birthweight infants fed either human milk or a preterm formula.

The mean rate of nitrogen retention in infants fed the formula feed was $377 \mathrm{mg} / \mathrm{kg} /$ day, which is similar to the fetal accumulation rate of nitrogen between 28 and 32 weeks of gestation (about $350 \mathrm{mg} / \mathrm{kg} /$ day). ${ }^{78}$ The infants fed human milk retained only about three quarters of this amount, the difference being explained by their lower nitrogen intake. The range of nitrogen intake seen in this study (337$678 \mathrm{mg} / \mathrm{kg} /$ day) corresponded to a protein intake of $2 \cdot 1-4 \cdot 2 \mathrm{~g} / \mathrm{kg} /$ day, and there was a positive linear correlation between the amount of retained nitrogen and nitrogen intake.

Energy retention was also higher in infants fed Pre-Aptamil. This, together with the higher nitrogen retention, explains their significantly greater weight gain. The differences observed between the nitrogen and energy balances in the two groups cannot be attributed to the groups being studied at different ages; the group fed Pre-Aptamil showed higher energy and nitrogen retention despite being studied earlier (although not significantly so) than the other group.

We found a positive linear correlation between nitrogen retention and energy retention (Figure). Nitrogen balance in adults is quickly affected by the amount of energy in the diet, and several studies in low birthweight infants have shown that correction of steatorrhoea, or increased energy intake, may improve nitrogen retention; ${ }^{9}{ }^{10}$ data are, however, lacking for very low birthweight infants.

In the present study we did not change the energy:nitrogen ratio of human milk, which varied considerably. Our multiple regression analysis of data from babies fed human milk shows that the most important factor affecting nitrogen retention is nitrogen intake. This conclusion does not apply to the group fed Pre-Aptamil because the protein:energy ratio was constant and so the data could not be analysed. Our data, therefore, confirm recent observations of better weight gain in infants fed with human milk supplemented with protein, compared with those whose milk was supplemented only with energy in the form of medium chain triglycerides. ${ }^{11}$
The energy in unpasteurised expressed breast milk and in modern preterm formulas is generally quite well absorbed by very low birthweight infants, ${ }^{1512}$ and it may be that energy is not always the limiting factor in growth that it was thought to be. It may become so, however, in infants with abnormally high energy expenditure, infection, or very poor absorption, but in healthy infants of very low birthweight, protein deficiency now seems to be the most likely cause of poor growth in nurseries that promote feeding with human milk. Consideration should be given to methods of estimation of the protein content of feeds, and to appropriate protein supplementation where necessary.

We thank Cara Kepson for technical assistance and the staff of the special care baby unit for their cooperation.

\section{References}

1 Atkinson SA, Bryan MH, Anderson GH. Human milk feeding in premature infants: protein, fat and carbohydrate balances in the first two weeks of life. J Pediatr 1981;99:617-24.

${ }^{2}$ Senterre J. Nitrogen, fat and mineral balance studies in low-birth-weight infants fed banked human milk or an experimental formula. In: Stern L, ed. Intensive care in the newborn, vol IV. New York: Masson, 1983; 89-95.

${ }^{3}$ De Curtis M, McIntosh N, Ventura V, Brooke OG. Effect of non-nutritive sucking on nutrient retention in preterm infants. J Pediatr 1986;109:888-9.

${ }^{4}$ Miller DS, Payne PR. A ballistic bomb calorimeter. Br J Nutr 1959;13:501-8

'Official methods of analysis of the Association of Official Analytical Chemists. 2nd ed. Washington DC: Association of Official Analytical Chemists. 1979.

${ }^{6}$ Brooke OG, Wood L, Barley J. Energy balance, nitrogen balance and growth in preterm infants fed expressed breast milk, a premature infant formula and two low solute adapted formulae. Arch Dis Child 1982;57:898-904.

7 Committee on Nutrition. Nutritional needs of low-birth-weight infants. Pediatrics 1977;60:519-30.

${ }^{8}$ Shaw JCL. Parenteral nutrition in the management of the sick low birth weight infant. Pediatr Clin North Am 1973;20:333-57.

9 Roy LL, Ste-Marie M, Chartrand L, Weber A, Bard H, Doray B. Correction of the malabsorption of the premature infant with a medium chain triglyceride formula. $J$ Pediatr 1975;86:446-50.

10 Tantibhedhyangkul P, Hashim SA. Medium chain triglyceride feeding in premature infants: effects on fat and nitrogen absorption. Pediatrics 1975;55:359-70.

"Rönnholm KAR, Perhecntupa J, Siimes MA. Supplementation with human milk protein improves growth of small premature infants fed human milk. Pediatrics 1986;77:649-53.

12 Reichman B, Chessex P. Putet G, et al. Dict, fat accretion, and growth in premature infants. N Engl J Med 1981;305:1495-1500.

Correspondence to Dr M De Curtis, Neonatal Unit, Second School of Medicine, Via Pansini 5, 80131 Naples, Italy.

Received 26 February 1987 